\title{
Analysis of The Impact of Covid 19 Pandemic on Halal Industry in Micro, Small and Medium Enterprises (MSMEs) and Economic Growth in Indonesia
}

\author{
Eko Siswoyo ${ }^{1^{*}}$ \\ ${ }^{1}$ Sharia Economics Department, Postgraduate Faculty, State Institute Islamic Studies (IAIN) Kudus
}

\begin{abstract}
The MSME-based halal industry is one of the potentials that must receive serious attention from the government. Since the World Health Organization declared the Covid 19 disaster to be a pandemic, it will certainly have an impact on various fields, especially the economic sector. This study aims to provide a comprehensive analysis of the halal industry and micro, small and medium enterprises in an effort to deal with the COVID-19 pandemic and its impact on economic growth in Indonesia. The method used is descriptive qualitative with a phenomenological approach. The data obtained were analyzed using qualitative analysis with data reduction, category and verification. The results of the study show the potential of the MSME sector even though its development in the midst of the Covid 19 pandemic experienced obstacles. The existence of support through creativity and innovation through the development of information technology can contribute to economic growth. However, the integrity of the halal industry needs synergy and support from the government, MSMEs, business people and the community so that they can still adapt to new economic patterns and help the economic recovery amidst the pandemic can be better.
\end{abstract}

Keywords: MSMEs, Halal Industry and Economic Growth

\section{INTRODUCTION}

The development of the micro, small and medium enterprise (MSME) industry, especially the halal industry in Indonesia, has received great attention from both the government and business actors. MSMEs have a major contribution to economic growth in Indonesia, starting from production output, employment absorption to becoming a contributor to the country's foreign exchange. The development of MSMEs is currently very

\footnotetext{
* Corresponding author: ekosiswoyo37@gmail.com
} 


\section{$A \bar{C} \overline{I E B} \quad$ Annual International Conference \\ on Islamic Economics and Business, 2021}

high due to the diversity of religions, cultural customs, and the potential of regions with abundant resources so that MSMEs in Indonesia are growing very fast and rapidly. Based on data from the Ministry of Cooperatives and SMEs, informal micro-enterprises in 2020 increased by 1.18 million people (2.62\%) from 45.07 million people to 46.25 million SMEs. The existence of small industries is increasingly felt by their important role in becoming one of the competitive advantages in facing global market competition. At first, MSMEs were only considered as an important source in creating job opportunities and dynamizing economic development in the regions. In addition, there is a very large market demand for halal products around the world, increasingly making the opportunities for MSMEs engaged in the halal industry increase and the opportunity to continue to grow is a distinct advantage. Plus, the Indonesian Muslim population is estimated at 273 million people or $87.2 \%$ of the total population in Indonesia (World Population Review, 2020). This is a challenge for the government, because the small industrial sector has high flexibility to change compared to large-scale companies. This then becomes a reference as a positive impact on the Indonesian economy as shown by the ongoing balance of payments, the decreasing number of unemployment rates and the increasing economy in the region.

The COVID-19 pandemic that has hit all countries in the world has an impact on various sectors, especially the economic sector. As a result, the pandemic has become a constraining factor in economic growth. According to the International Monetary Fund (IMF) projecting the economy will experience a decline of 3\%. In addition, Covid 19 pandemic based on the Organization for Economic Co-operation and Development (OECD) report will affect the economy in terms of supply and demand for goods from various sectors around the world. From the supply side, the company will reduce the supply of raw materials and the number of workers who are not healthy and there are factors from the production and supply chain that are also experiencing problems. Meanwhile, from the demand side, the lack of demand and the declining purchasing power of consumers are the biggest inhibiting factors for product sales by the company, plus the decline in consumer confidence in a product. Facts show that the COVID-19 pandemic has had a negative impact on the economic sector, including small and medium enterprises (MSMEs). Behind the decline in MSME income during the pandemic, business actors must survive in the midst of difficult conditions for national economic stability.

Industrial development is predicted to continue to experience growth if it meets several aspects including financial management, capital, production, human resources and marketing (Abdul, 2013). The Indonesian economy is the most important main issue, especially with its influence at this time with Covid 19 pandemic being a challenge for all parties. The effect of this pandemic is very large on conditions in society which are increasingly difficult to meet their daily needs, because many sectors are neglected and make workers lose their jobs and livelihoods, including cessation of operational activities from the MSME sector. As a result, the increase in unemployment causes a slowdown in economic growth in the regions which of course has an impact on the national economy. This is due to competition and the declining purchasing power of consumers. The condition of declining competitiveness of MSMEs is indicated by the low selling power of MSME products. Therefore, to support sustainability of the existence of groups from the MSME sector, it must be managed properly during the current pandemic and should get more attention from the government so that these businesses can continue to experience growth. Based on background and phenomena that occur, the researcher aims to conduct research to provide an overview analysis of condition by MSMEs in Indonesia in the midst of Covid 19 pandemic that is currently hitting and its impact on economic growth in Indonesia. 


\section{RESEARCH METHODS}

This type of research is descriptive qualitative with a phenomenological approach. The research uses content analysis techniques and library research in obtaining data from scientific journals, reference books and other relevant data sources. The content analysis technique is a research method used to find out the conclusions from revealing the author's manifested and latent ideas. While library research is a research method based on secondary data sources. The data obtained were then analyzed descriptively by providing explanations in the form of sentences, pictures, tables, symbols associated with the object in this study. The phenomenological approach in this study aims to understand the phenomenon of what is experienced by research subjects holistically and by way of description in the form of sentences in a natural context and by utilizing various scientific methods (Moleong, 2007).

The data analysis used in this study went through three stages. First, data reduction by selecting all data through cutting and simplifying existing data according to the research topic. Second, data categorization by continuing from the reduction process based on categories by adjusting the research data. Third, data verification, namely by making conclusions which are interpretations of data from researchers. In general, this is done by using triangulation techniques through comparisons between one data source and other data sources (Neuman et al, 2014).

\section{RESULTS AND DISCUSSION}

\section{Strengths and Weaknesses of the MSME Sector}

The MSME sector has great potential as part of supporting economic growth in Indonesia. Business development must be followed by good management and planning that will minimize failure, mastery of knowledge will support the sustainability of the business, cultivate an efficient and effective production system and make breakthroughs and innovations that make a difference in competition are steps towards success in managing the business. There are several advantages in a micro, small and medium enterprise (MSME) including the quality of the product produced is good, namely by prioritizing the quality of the product to be sold, the existence of a good relationship between producers and consumers by providing the best quality products and guarantees if the product is defective for maintain customer satisfaction. While the weaknesses of MSMEs include management that is still not neat, it can be seen from the activity of purchasing raw materials, the absence of records and archives related to financial administration and not recorded in the financial statements. Product distribution is not good, which can be seen from the process of distributing products to consumers that is still less efficient and not on time, Promotion and minimal MSME capital, And human resources who have skills that do not match the needs of the business business will hinder the development of SMEs in the future (Alfi et al, 2012). However, some aspects of the strengths and weaknesses that exist in an MSME become an opportunity for the halal industry to be developed and avoided in accordance with the needs of running business conditions by taking into account the needs that can cause the weakening of the business being involved.

\section{MSMEs Development Strategy based on Halal Industry}

MSMEs based on halal industry are all stages of the process that do not violate the rules of Islamic law to produce halal products. To develop halal products, one of the strategy efforts that can be done. First, by strengthening halal products through halal 


\section{$A I \overline{I E B} \quad$ Annual International Conference \\ on Islamic Economics and Business, 2021}

labels/certifications by authorized institutions. Not only the Muslim community, nonMuslims are also starting to realize the benefits of halal products starting from cleanliness, safety, nutritional content and so on. Changes in consumer lifestyles have an impact on the increasing demand for products from the halal industry in the global market. Awareness about the importance of halal products is not only a concern of consumers as product buyers but from halal industry business actors or producers as providers of halal products. With the emergence of an increasing trend of halal products, consumers are starting to become aware of a halal lifestyle who cares about the benefits of a product (Pujiono et al, 2018). Therefore, there is a change in the pattern of consumers who are increasingly interested in the need for halal products, it is necessary to have halal product certification from MSME actors. This condition does not stop at certification, MSMEs must improve their branding position, promote Halal awareness and halal lifestyle as a competitive advantage in increasing the competitiveness of halal products so that they can be exported to countries around the world who have interest and concern for halal products.

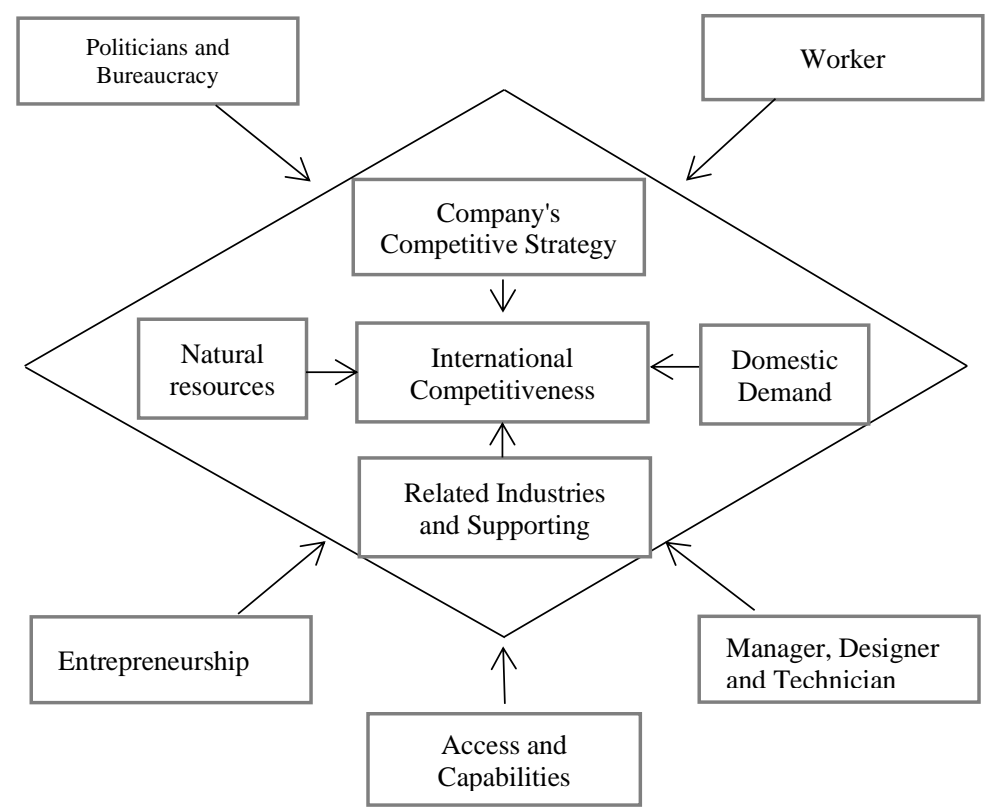

Figure 1. 9 Factors Competitiveness Model (Cho, 2003)

The second MSME development strategy is to increase the market reach of the halal industry. The large quantity of halal product consumers will certainly provide significant opportunities for the development of halal industry. With the guarantee of halal food safety for consumers and high export potential, producers will strive to continue to develop and increase production to fill the world market and expand the export distribution network of halal products (Heidarzadeh, 2011). According to a report from the State of The Global Islamic Report (2020) there are around 1.95 billion Muslim residents worldwide who are consumers of the halal industry. This potential increases by $5.2 \%$ every year with total consumer spending reaching USD 2.2 billion. The Muslim community will be the main target as consumers for halal product producers. The largest market is still in Asia Pacific which is still a potential market for export activities, in addition to the domestic market which is quite large. Then markets in North Africa and the Middle East with large Muslim populations will be very profitable for marketing halal products from Indonesia. In addition, countries with 


\section{$A I \overline{C E B}$ Annual International Conference \\ on Islamic Economics and Business, 2021}

low Muslim populations such as the United States, Australia and European countries also have an interest in halal products. This is due to quality factors specifically such as in the food sector, products from the halal industry still have different taste qualities, better safety levels and are hygienic (Lady, 2015). Based on data from the Ministry of Trade, there are 3 policies issued by the government to maximize export potential. First, utilizing policy instruments with export and import relaxation for halal products for export purposes. Second, Improving market access for Indonesian products in the global market by using good facilities. Third, strengthening the halal export business sector. One of the concrete steps taken is halal certification for the MSME sector. The opportunity for the MSME sector is very potential to be able to contribute in various sectors in indonesia with halal product innovation to help increase the availability of halal products and the quality produced as an effort to expand the export reach of halal products from Indonesia.

The third development strategy is to increase the promotion of halal products. In increasing export market share, promotional activities are very important in supporting the successful development of the halal industry. According to the Ministry of Trade, to realize the halal industry from Indonesia to become the center of the world's halal producers is something very complex. This is related to the synergy of many parties between the government, the private sector, SOEs, MSMEs, business actors and the public in general. On the other hand, export activities will also encourage advertisers to participate as business opportunities. The advertising sector will assist in the development of halal products broadly for companies and halal product inspection agencies in providing information and communication services for consumers. According to Kotler (2001) marketing communication (promotional mix) is a special blend of advertising, personal selling, sales promotion and public relations that a company uses to achieve its advertising and marketing objectives. Promotion itself has several goals such as modifying behavior, providing information to consumers and explaining the importance of a product so that with this promotion consumers become familiar with halal products as a result, it will attract purchasing power for the product (Lamb, 2001). Without an adequate mentality and material supported by fulfilled substances, it will be an opportunity for the Indonesian halal industry to become a major player in the halal product market in the world.

\section{Impact of Covid 19 Pandemic on Economic Growth}

According to sources from the Central Statistics Agency (BPS) in 2020 Indonesia's GDP level based on current prices reached IDR15.434,2 billion and GDP Per capita reached IDR 56.9 Million or USD 3.911,7. Several government policies have been made as an effort to deal with the Covid-19 pandemic, such as direct cash assistance, deferral of tax payments, suspension of electricity costs for the lower classes of society, pre-employment assistance, salary subsidies for employees with low incomes and so on whose value reaches IDR 600 billion (Ana toni et al, 2021). Various fiscal sources have been mobilized starting from taxes, budget relocation and issuance of debt securities. This step was taken by the government as an effort to restore the national economy. In addition, the current policy implementation continues while looking for better formulas and fiscal sources to maintain the Indonesian economy during the Covid-19 pandemic.

International Monetary Fund (IMF) it is predicted that during Covid 19, advanced countries will experience a contraction in economic growth between -5.5\% (Germany) to $15.4 \%$ (US). The average growth of developed countries is predicted to be $-10.7 \%$. Meanwhile, middle and developing countries (Emerging Country and Middle Country) contracted between $-4.8 \%$ (Russia) to $-13.3 \%$ (South Africa) with an average economic growth of $-5.7 \%$. 
Table 1. Comparison of growth and impact of covid 19

\begin{tabular}{|l|l|}
\hline \multicolumn{1}{|c|}{ Period } & Growth \\
\hline Triwulan I-2020 & $2,97 \%$, \\
\hline Triwulan II-2020 & $-3,52 \%$ \\
\hline Triwulan III-2020 & $-3,49 \%$ \\
\hline Triwulan IV-2020 & $-2,19 \%$ \\
\hline Triwulan I-2021 & $0,74 \%$ \\
\hline Triwulan II-2021 & $7,07 \%$ \\
\hline Triwulan III-2021 & $3,51 \%$ \\
\hline
\end{tabular}

Sources : (Processed data, 2021)

Indonesia as a developing country category must be vigilant because at a glance the effects of economic contraction faced by poor countries are relatively smaller than developing and developed countries (Dedi et al, 2021). At the beginning of the Covid 19 pandemic, economic growth in Indonesia, namely the first quarter of 2020 was $2.97 \%$, the second quarter of 2020 decreased at $-3.52 \%$, the third quarter of 2020 was not much different, it was still at $-3.49 \%$ and the fourth quarter continued decreased by $-2.19 \%$. Indonesia's economic growth experienced a slowdown when compared to the previous year. Starting in 2021 , the economy has slightly improved significantly. In the first quarter of 2021, economic growth has started to grow positively, which is $0.74 \%$, then it will continue in the second quarter of 2021, increasing to $7.07 \%$ and growing by $3.51 \%$ in the third quarter of 2021 (Central Bureau of Statistics, 2021). When viewed from existing data and compared to 2020, the Covid 19 pandemic has a negative impact on Indonesia's growth. The MSME sector during the pandemic also experienced various problems and hampered business development. With the total number of MSMEs in Indonesia reaching 64.19 million, the composition of Micro and Small Enterprises is very dominant, namely 64.13 million (99.92\%) of the entire business sector. This group is also one of the sectors affected by the Covid 19 pandemic. According to a survey conducted by the Indonesian Business Development Service Association, the total surveyed were 6000 MSMEs. The results show that $26.6 \%$ of them experienced a decrease in business activity by more than $60 \%$ during the Covid 19 pandemic. Meanwhile, MSMEs that were unable to do business at all reached $36.7 \%$ of the total survey respondents. This data can represent the condition of MSMEs during the pandemic in Indonesia. With these conditions, more attention is needed from the government as a stakeholder. Therefore, the government issued several policies aimed at saving the national economy. There are government policies to overcome economic problems which are divided into 2 parts. First, related to social security by adding and supporting State Revenue and Expenditure Budget (APBN) financing. Second, economic security by providing fiscal and non-fiscal incentives. In addition, there are other stimulation issued by the government to improve the economy, such as government regulation number 1 of 2020 concerning state financial policies and financial system stability for national handling and government regulations in the tax sector (Rianda, 2021). So that with the government's policy to overcome economic problems that were hit by Covid 19, it is considered quite effective.

\section{CONCLUSION}

The impact of Covid 19 felt by Indonesia in all sectors resulted in a decline in economic growth. The Halal Industry from the Micro, Small and Medium Enterprises (MSME) sector as one of the potential sectors and has a big impact on the economy also experienced many 


\section{$A \mathrm{ICB}$ Annual International Conference \\ on Islamic Economics and Business, 2021}

obstacles that caused a decrease in MSME business activities. The inhibition of economic growth due to the pandemic, ranging from a decrease in business activity in the halal industry MSME sector to the decline in consumer purchasing power, has further exacerbated the situation in the halal industry. As a result, the development of the MSME sector also slowed down and even continued to experience a drastic decline during the pandemic. The development of a MSME-based halal industry development strategy starting from the use of export and import activity instruments by increasing market access to Indonesian halal products to strengthening the export business sector is a hope with the potential for MSMEs to be able to return to growth and continue to grow even though Covid 19 pandemic is still hitting Indonesia. The government issued various policies whose purpose was to save the national economy. Although the government's policies cannot be felt in the short term, they are at least able to withstand the decline in numbers from the minus of economic growth that is getting worse. In order to experience positive economic growth again, it will be felt in the medium and long term.

\section{REFERENCES}

A. Pujiono, R. Setyawati, and I. Idris, "Strategi Pengembangan Umkm Halal Di Jawa Tengah Dalam Menghadapi Persaingan Global," Indonesia Journal of Halal, vol. 1, no. 1, pp. 1-7, Oct. (2018).

Abdul Muin. (2013). Faktor yang Mempengaruhi Perkembangan Klaster Batik Laweyan Surakarta Menuju Ekonomi Lokal Berkelanjutan. Magelang: Jurnal Wilayah dan Lingkungan. Vol. 1, No. 1.

Alfi Amalia, Wahyu Hidayat, Agung Budiatmo. (2012). Analisis Pengembangan Usaha Pada Usaha UMKM Batik Semarang Di Kota Semarang. Jurnal Ilmu Administrasi Bisnis.

Ana Toni Roby Candra Yudha dan Abdullah Kafabih. (2021). Halal Industry during the Covid-19 Pandemic is The Hidden Blessing. el-qist, vol. 11, no. 1, pp. 17-32.

Asosiasi Business Development Sevices Indonesia (ABDSI). 2021. Data BDS-P di Indonesia. Di akses 21 November 2021.

Badan Pusat Statistik. 2021. Laporan Pendapatan Nasional Indonesia 2015-2020. Diakses pada 19 November 2021.

Cho, Dong Sung. 2003. From Adam Smith to Michael Porter: Evolusi Teori Daya Saing. Jakarta: Salemba Empat

Dedi Junaedi dan Faisal Salistia. (2020). Dampak Pandemi Covid 19 Terhadap Pertumbuhan Ekonomi Negara-Negara Terdampak. Simposium Nasional Keuangan Negara. Hal 995.

Heidarzadeh, Kambiz, "Intention To Halal Products In The World Markets, Interdisciplinary Journal of Research in Business," Tehran: Department of Business Management, Science and Research Branch Islamic Azad University Vol. 1,(2011).

Kementerian Koperasi dan UKM. (2021). Tidak Ada Pengurangan Jumlah Pelaku Usaha Formal Dan Informal Hingga 30 Juta Orang. Diakses 21 November 2021.

Kementerian Perdangangan. (2020). Strategi Pemerintah Meningkatkan Ekspor Produk Halal. Diakses 21 November 2021.

Kotler, Philip dan Gary Armstrong. (2001). Prinsip-prinsip Pemasaran. Terjemahan Damos Sihombing, M.B.A. Jilid 1. Jakarta : Erlangga.

Lady Yulia. 2015. Strategi Pengembangan Industri Produk Halal. Jurnal Bimas Islam Vol.8. No.I

Lamb, Charles W, Joseph F. Hair, Carl McDaniel. (2001). Pemasaran. Terjemahan David Octarevia . Edisi Pertama. Jakarta : Salemba Empat. 


\section{$A T \bar{C} \quad$ Annual International Conference \\ on Islamic Economics and Business, 2021}

Moleong, Lexy J. (2007). Metodologi Penelitian Kualitatif. Edisi Revisi. Bandung : PT Remaja Rosdakarya.

Neuman, W.L., Djamba, Y.K. (2014). Social Research Methods: Qualitative and Quantitative Approaches. 7th ed. USA: Pearson.

Organisation for Economic Co-operation and Development. (2020). SME Policy Responses. Diakses pada 20 November 2021.

Rianda Dirkareshza, Dinda Maurizka Azura dan Roni Pradana. (2021). Kebijakan Pemerintah di Masa Pandemi Covid 19: Antara Negara Sejahtera dan Negara Sehat. Jurnal Mercatoria, 14 (1) Juni Hal 46:55.

State of Global Islamic Economy Report. (2020). State of Global Islamic Economy Report 2019/20. New York: Thomson Reuters.

World Population. (2020). Retrieved, November 19, 2020, from World Population Review : http://worldpopulationreview.com/ 